\title{
CAMPYLOPUS SUBULATUS SCHIMP. EX MILDE AND FOSSOMBRONIA INCURVA LINDB. ARE NOT MEMBERS OF THE HUNGARIAN BRYOPHYTE FLORA
}

\section{Peter Erzberger}

Belziger Str. 37, D 10823 Berlin, Germany, E-mail: erzberger.peter@gmail.com

Correction of Errata in ABPA 5(1): 33 (2017): Erzberger et al:: Remarkable finds of bryophytes in Hungary during the last two years (2015-2017).

In my lecture 'Remarkable finds of bryophytes in Hungary during the last two years (2015-2017)' two species were erroneously reported from Hungary, the specimens were misidentified or in the case of a third species doubtful:

- Campylopus subulatus - delete. The plants from Jeli Arborétum were a form of $C$. pyriformis.

- Fossombronia incurva - delete. The specimens represent $F$. pusilla with immature spores.

- Riccia beyrichiana - doubtful.

One of the locations given for Syntrichia ruralis var. epilosa is also erroneous - delete Keszthelyi-hg. 9270.1, the specimen represents $S$. montana var. calva (rev. Gallego); the record from Kőszegi-hg. 8665.1 is correct (det. Gallego).

Stunted plants of Campylopus pyriformis sometimes lack stereids in the cross section of the costa and can then be confused with $C$. subulatus (Smith 2004). In Jeli Arborétum we found two different forms of $C$. pyriformis, which are also known as mod. fragilis and mod. muelleri (Frahm and Frey 2004). They differ in the means of vegetative propagation: In mod. fragilis, specialized short leaves with a concave ovate base are often scattered above the plants (Figure 1), whereas in mod. muelleri the deciduous leaves are 

excluded from Hungary

normal in shape. However, sometimes the plants produce also shoot tips that break off (Figure 2), these plants show some resemblance to $C$. subulatus. We thought that two plants as different in habit must be two different species, but careful examination and comparison with authentic material led to the conclusion, that both forms belong to $C$. pyriformis.

I gratefully acknowledge the help of the late W. Schröder and L. Meinunger and of M.T. Gallego, Th. Homm and M. Reimann in the revision of our specimens.
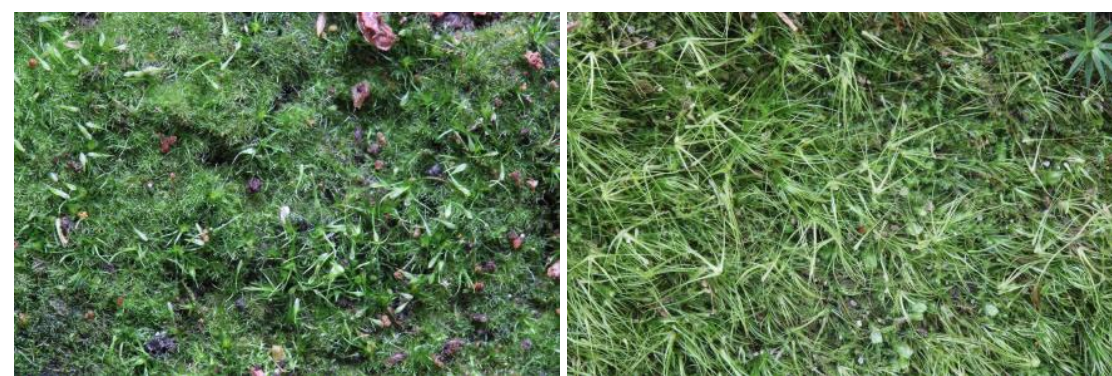

Figure 1 and 2. Campylopus pyriformis, Jeli Arborétum (Photo: Cs. Németh)

\section{REFERENCES}

Erzberger, P., NÉmeth, Cs., Nagy, J., Baráth, K., Csiky, J., Eckstein, J., Mesterházy, A., Kovács, A. \& PAPP, B. (2017). Remarkable finds of bryophytes in Hungary during the last two years (2015-2017) (Az elmúlt két év (2015-2017) magyarországi mohaflorisztikai kutatásainak jelentősebb eredményei). Acta Biologica Plantarum Agriensis 5(1): 33. https://doi.org/10.21406/abpa.2017.5.1.33

FRAHM, J.-P. \& FREY, W. (2004). Moosflora. 4th. ed. Ulmer, Stuttgart, 538 pp.

Sмith, A.J.E. (2004). The Moss Flora of Britain and Ireland. (2nd ed.) University Press, Cambridge, $1012 \mathrm{pp}$. 